\title{
Assessment of respirable particulates in two residential areas of Kuwait State during dusty and nondusty storms: A time-series comparative study
}

\section{Original Article}

\author{
Gehan R. Zaki', Ahmed I. Issa', Adel M. Refaat', Wafaa M. Eid ${ }^{3}$,Abdel-Aziz K. \\ Abdel-Aziz ${ }^{1}$
}

${ }^{1}$ Department of Occupational Health and Air Pollution, High Institute of Public Health, Alexandria University, Alexandria, Egypt

${ }^{2}$ Department of Science, Public Authority for Applied Education and Training, Kuwait University, Kuwait City, Kuwait

${ }^{3}$ Department of Air Pollution Measurements, Ministry of Health, Kuwait

\begin{abstract}
Background: Kuwait State is branded by the recurrent dust storms and high pollution level. It has the highest dust concentration and surface temperature in Peninsula. The aim of the present study was to assess the respirable particulates during days with and without dust storms in two residential areas in Kuwait State.

Materials and Methods: This time-series comparative study was accomplished during the period from 1 January 2013 to 31 December 2013. It was conducted by recording the local meteorological data in the two sampling stations at Mansoria (A) and Ali Sabah Al-Salem (B) residential areas, in addition to the sampling and analysis of respirable particulates (PM10) using the SOP-10 High-Volume PM10 Samplers' Standard Method.

Results: There were 256 and 278 measurement days (70.1 and $75.1 \%$ of the yearly days) in monitoring stations A and B, respectively, with a total of $119(46.5 \%)$ and 134 (48.2\%) days with dust storms, respectively. The daily concentrations of PM10 were higher than the National Ambient Air Quality Standards of Kuwait State $(150 \mu \mathrm{g} / \mathrm{m} 3)$ at the two stations. The annual PM10 concentration of B station [192.5 (264.5) $\mu \mathrm{g} / \mathrm{m} 3$ ] was nonsignificantly higher than that of A [191.2 (182.7) $\mu \mathrm{g} / \mathrm{m} 3$ ]. At the two stations, the levels of PM10 during days with dust storms were significantly higher than that during days without.

Conclusion: Respirable particulate is slightly higher in Ali Sabah Al-Salem than in Mansoria. Days with dust storms have significantly greater PM10 levels than those without. The study recommends application of land-use planning, and windbreaks, combating desertification, and enhancing stoppage of outdoor activities during dust storms among public.
\end{abstract}

Received: 12 Aug 2017, Accepted: 15 Jan 2018

Key Words: Ali Sabah Al-Salem, dust storms, Kuwait State, Mansoria, residential areas, respirable particulates.

Corresponding Author: Gehan R. Zaki, Ph.D., Department of Occupational Health and Air Pollution, High Institute of Public Health, Alexandria University, Alexandria, Egypt, Tel.: +20 3426 6512/+20 100331 2642, E-mail: gehanra@alexu. edu.eg

ISSN: 0013-2446, Vol. 92, No.2

\section{INTRODUCTION}

Dust storms are a natural phenomenon, in which dust particles can travel up to thousands of kilometers, resulting in high ambient dust concentrations. This means that pollutants emitted in a certain area worldwide can affect the concentrations in all countries. It is considered as one of the signs of desertification ${ }^{[1]}$. Dust storms transport yearly $\sim 2.2$ billion tons of soil and dry sediments throughout the earth $^{[2]}$. Furthermore, many studies reported increased hospital admittance for respiratory and cardiovascular diseases owing to exposure to dust storms ${ }^{[3,4]}$. In addition to the public health effects, the agriculture, air traffic, and tourism are also affected ${ }^{[5-7]}$. Dust storms have great environmental effects, including reduction of visibility, soil erosion, ground water salinization, and climatic change. Moreover, it may cause disease transmission, air pollution, closing of businesses, car ignition failure, road accidents, stoppage of electrical insulators, and drinking water contamination ${ }^{[2,8,9]}$.

Dust particles are classified into fine and respirable. Most of the fine particulates (PM2.5) originate from industrial sources such as fossil-fuel combustion. They have a huge influence on health owing to penetration of the deepest parts of the lungs. Respirable particulates (PM10) are mainly of natural sources such as soil and crustal materials. They are the dominant part of dust during dust storms ${ }^{[1]}$. The PM10 concentrations vary according to its source (man-made or natural); in addition, the meteorological parameters are the main factors affecting it. Dust storms are one of the major natural sources of respirable particulates in Kuwait 
State $^{[10,11]}$. Several European ${ }^{[3,12]}$, USA $^{[13]}$, Middle East ${ }^{[7,14]}$, Kuwait $^{[15,16]}$, and Chinese studies ${ }^{[17]}$ revealed high risk of lung cancer, heart diseases, and chronic obstructive lung diseases among those exposed to PM10.

Kuwait is a subtropical desert in the Arabian Peninsula. It has a large petroleum industry that affects the urban land use. Air quality in Kuwait's state is influenced by multiple factors that increase the state's energy demands, including topography, meteorology, socioeconomic development, population growth, and the elevated rate of industrialization and urbanization. It is branded by the recurrent dust storms and high pollution level. It has the highest dust concentration and surface temperature in Peninsula ${ }^{[18-20]}$. In residential areas, the levels of PM10 are influenced by the presence of the surrounding human activities, such as traffic, commercial, and industrial. Mansoria and Ali Sabah Al-Salem are two residential areas in Kuwait with various surrounding activities.

The aim of the present study was to assess the respirable particulates during days with and without dust storms in two residential areas in Kuwait State (Mansoria, and Ali Sabah Al-Salem).

\section{MATERIALS AND METHODS}

This time-series comparative study was accomplished during the period from 1 January 2013, to 31 December 2013. It was conducted by recording the local meteorological data, in addition to the daily sampling and analysis of respirable particulates (PM10). PM10 concentration was used in the present study as an indicator of the dust storm (El-Tows) phenomenon ${ }^{[7]}$.

The study was performed in two residential areas in Kuwait State, Mansoria and Ali Sabah El-Salem. These two areas were selected specifically because they represent $50 \%$ of the total number of residential areas, one of which lies in the north and the other in the south, and the feasibility is a further reason of selection. The first is located in the north of Kuwait with residential and commercial activities. It is surrounded by heavy traffic roads, including Jassim Mohamed El-Wazzan, Cairo, Khalid Yousef El-Marsouk, and Issa Abdulla Bahmin Streets. Mansoria is close to Kuwait's bay and the Arabian Gulf. The sampling station was located above the polyclinic of Al-Mansoria at $29.360108^{\circ} \mathrm{N}$, and $47.997259^{\circ} \mathrm{E}$ (Fig. 1) ${ }^{[15]}$.

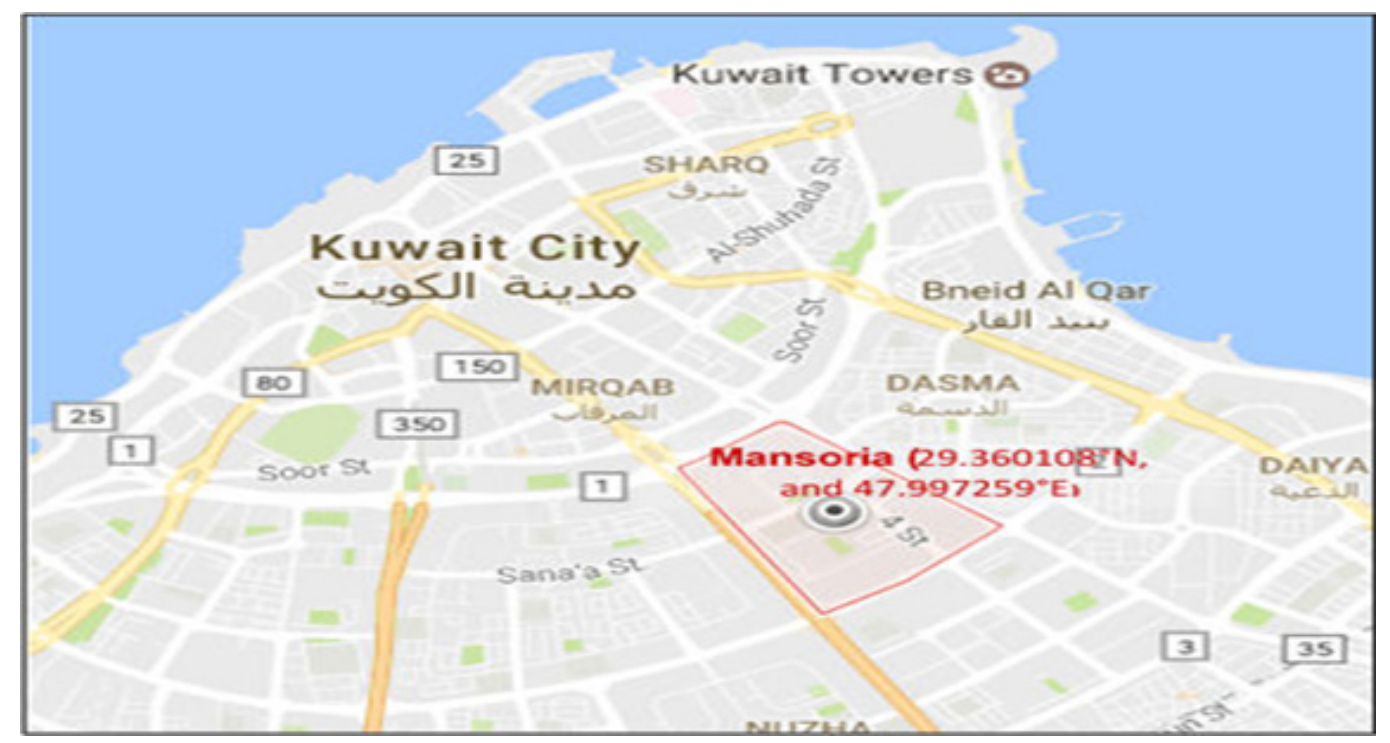

Fig. 1: Location of Mansoria Sampling Station, Kuwait, at $29.360108^{\circ} \mathrm{N}$, and $47.997259^{\circ} \mathrm{E}$.

Ali Sabah Al-Salem is a residential area located in Southern Kuwait. It is bounded on the west and south by the King Fahad Bin Abdulaziz road, on the north by the Wafrah road, and on the east by the Fahaheel Expressway/ Saudi road. It is $\sim 1 \mathrm{~km}$ from the Arabian Gulf coast. The industrial areas of harbor Abdulla and Shuaibah are located within $2 \mathrm{~km}$ to the north and north-north west of Ali-
Sabah-Al-Salem. It is surrounded by four industrial areas, including the eastern Shuaiba industrial area to the north, the western Shuaiba industrial area to the north-west, the Greater Burgan oil field to the northwest and west, and Umm Al-Hayman wastewater treatment plant to the southeast. The sampling site is located above the National Bank of Kuwait at $28.962276^{\circ} \mathrm{N}, 48.160023^{\circ} \mathrm{E}$ (Fig. 2) ${ }^{[16]}$. 


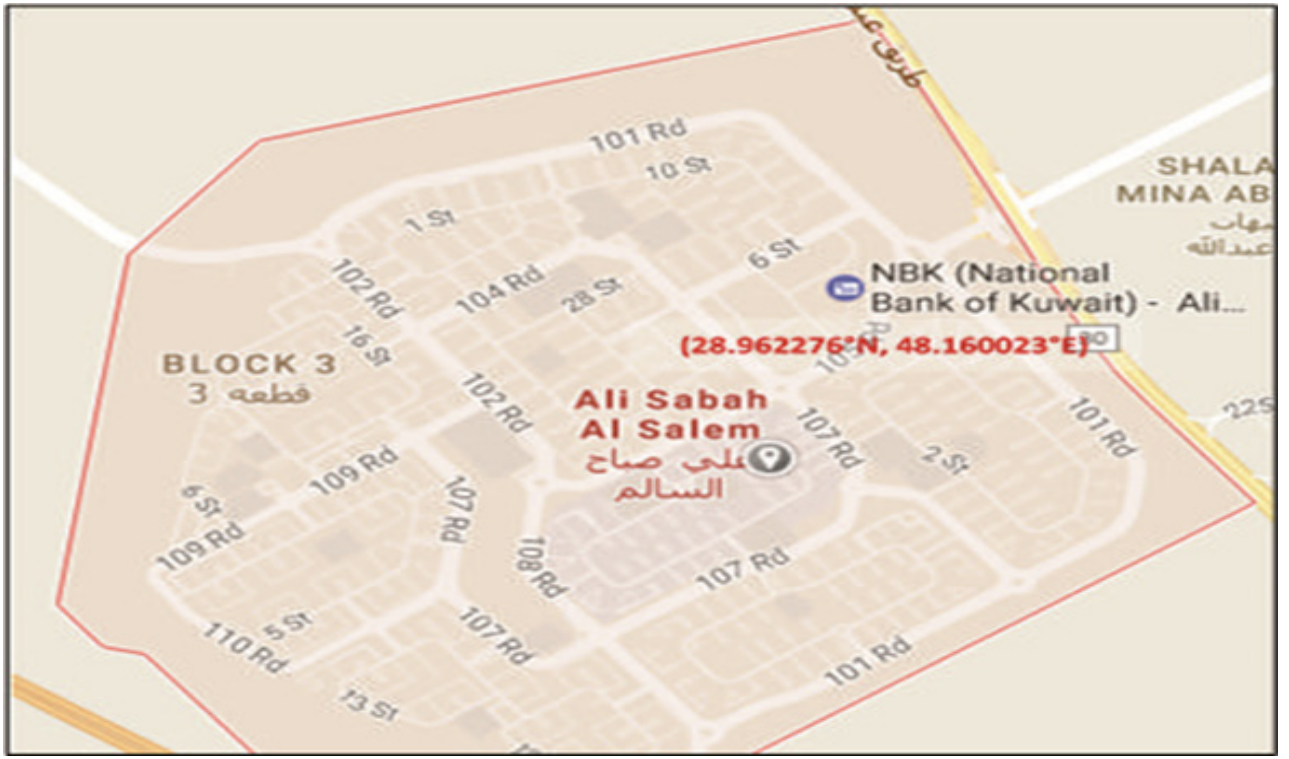

Fig. 2: Location of Ali Sabah Al-Salem Sampling Station, Kuwait, at $28.962276^{\circ} \mathrm{N}, 48.160023^{\circ} \mathrm{E}$.

Respirable particulates were sampled using PM10 high-volume air sampler Tisch Environmental Inc. TE6000 series. US. EPA Federal References Number RFPS0202-141 according to SOP-10 PM10 High Volume Air Sampler Standard Methods ${ }^{[21]}$. Sampling stations were placed on the roof of the buildings, at a height of $5 \mathrm{~m}$ above the ground levels. For quality control of data, the overall equipment was periodically maintained. The operators were trained twice a year. The instruments were calibrated monthly, and the work stations were regularly audited. The measurement days were categorized into days with and without dust storms according to the PM10 concentrations.

Each of the Met-One meteorological stations of KNMN is fixed on a $10-\mathrm{m}$ tower and has four main components. The first part was the one that has combined wind speed and direction sensor (sonic type wind sensor) at the 10-m height [(Met-One/Model: 50.5) uncertainty: $\pm 0.2 \mathrm{~m} / \mathrm{s}$ $(\leq 11.3 \mathrm{~m} / \mathrm{s})$ or $\pm 2 \%(\geq 11.3 \mathrm{~m} / \mathrm{s})$ wind speed, $\pm 3^{0}$ wind direction]. The second was the combined relative humidity and temperature sensors (capacitive/resistive type sensor) with solar shield (Met-One/Model: 083E/Uncertainty: $\pm 2 \% \mathrm{RH}, \pm 0.1^{\circ} \mathrm{C}$ ). The third part was the atmospheric pressure sensor (Met-One/Model: 090D/Uncertainty: $\pm 1.35 \mathrm{mBar} / \pm 1.25 \%$ FS). The two meteorological stations were equipped with data logger to measure the sensors, store both data and programs, and communicate via modems (Campbell Scientific/Model: CR3000), and GSM/GPRS modem for wireless communication (Sierra wireless/Model: Fastrack Xtend).

\section{Statistical analysis}

The data were statistically analyzed using IBM SPSS statistics version 21 (IBM Corporation, Armonk, NY: IBM). The measurement days were classified into with $(>200 \mu \mathrm{g} / \mathrm{m} 3)$ and without $(\leq 200 \mu \mathrm{g} / \mathrm{m} 3)$ dust storms according to the concentration of PM10 ${ }^{[7]}$. One-sample
Kolmogorov-Smirnov test was conducted to check the distribution of the variables. Kruskal-Wallis H-test was used to check the significance of variations of variables with more than two independent categories, with 95\% confidence interval (CI). Mann-Whitney U-test was used to check the significance of variations with variables with two independent categories, with $95 \%$ confidence interval $(\mathrm{CI})^{[22,23]}$. Differences at P-value up to 0.05 are considered significant.

\section{RESULTS}

The highly significant one-sample KolmogorovSmirnov test indicates that the main variable (PM10 concentration) was nonparametric. So, all variables were expressed in the present study as median (interquartile range).

There were 256 measurement days $(70.1 \%$ of the yearly days) in Mansoria monitoring station, with a total of 119 days with dust storms (46.5\%). In Ali Sabah AlSalem station, there were 278 sampling days $(75.1 \%$ of the yearly days), with a total of 134 days with dust storms $(48.2 \%)$. The total number of measurements was different in the two areas owing to different maintenance and calibration times in the two areas. Percentage days with dust storms during January, March, April, May, June, July, and August in Ali Sabah Al-Salem (37.50, 68.18, $50.00,60.87,86.21,81.48$, and $60.87 \%$, respectively) were higher than that in Mansoria $(30.43,40.00,47.62$, $50.00,80.77,80.00$, and $33.33 \%$, respectively). In contrast, they were lower in Ali Sabah Al-Salem during February, September, October, November, and December. In addition, $100 \%$ of the sampled weekends (Saturday and Friday) and $43.15 \%$ of the weekdays in Mansoria were days with dust storms. In Ali Sabah Al-Salem, $85.71 \%$ of Saturdays, $93.75 \%$ of Fridays, and $44.04 \%$ of weekdays were days with dust storms. The annual median of PM10 
concentrations in Mansoria monitoring station [191.21 (182.66) $\mu \mathrm{g} / \mathrm{m} 3$ ] was nonsignificantly lower than that in Ali Sabah Al-Salem [192.47 (264.46) $\mu \mathrm{g} / \mathrm{m} 3$ ] (Table 1). The daily concentrations of PM10 were greater than the National Ambient Air Quality Standards of Kuwait State $(150 \mu \mathrm{g} / \mathrm{m} 3)$ in both Mansoria and Ali Sabah Al-Salem (Fig. 3). Kruskal-Wallis test revealed that the PM10 concentrations in both Mansoria and Ali Sabah Al-Salem showed highly significant variations among different days $(\mathrm{P}<0.05,95 \% \mathrm{CI})$. Further analysis using Mann-Whitney test showed significant variation in PM10 concentrations during Saturday and Friday and during other working days in both Mansoria and Ali Sabah Al-Salem $(P<0.05,95 \% \mathrm{CI})$.

Table 1: Monthly and daily numbers and percent of days with dust storms in Mansoria and Ali Sabbah Al-Salem areas, Kuwait, 2013

\begin{tabular}{|c|c|c|c|c|}
\hline \multirow{2}{*}{ Months } & \multicolumn{2}{|c|}{ Mansoria station } & \multicolumn{2}{|c|}{ Ali Sabah Al-Salem station } \\
\hline & $\mathrm{N}(\mathrm{T})^{\mathrm{a}}$ & $\%^{\mathrm{b}}$ & $\mathrm{N}(\mathrm{T})^{\mathrm{a}}$ & $\%^{\mathrm{b}}$ \\
\hline January & $7(23)$ & 30.43 & $9(24)$ & 37.50 \\
\hline February & $6(19)$ & 31.58 & $4(21)$ & 19.05 \\
\hline March & $8(20)$ & 40.00 & $15(22)$ & 68.18 \\
\hline April & $10(21)$ & 47.62 & $11(22)$ & 50.00 \\
\hline May & $9(18)$ & 50.00 & $14(23)$ & 60.87 \\
\hline June & $21(26)$ & 80.77 & $25(29)$ & 86.21 \\
\hline July & $20(25)$ & 80.00 & $22(27)$ & 81.48 \\
\hline August & $7(21)$ & 33.33 & $14(23)$ & 60.87 \\
\hline September & $12(20)$ & 60.00 & $11(23)$ & 47.83 \\
\hline October & $9(19)$ & 47.37 & $3(19)$ & 15.79 \\
\hline November & $4(19)$ & 21.05 & $1(19)$ & 5.26 \\
\hline December & $6(25)$ & 24.00 & $5(26)$ & 19.23 \\
\hline Total & $119(256)$ & 46.48 & $134(278)$ & 48.20 \\
\hline Annual median of PM10 $(\mu \mathrm{g} / \mathrm{m} 3)$ & \multicolumn{2}{|c|}{$191.2(182.7)$} & \multicolumn{2}{|c|}{$192.5(264.5)$} \\
\hline
\end{tabular}

${ }^{\mathrm{a}} \mathrm{N}(\mathrm{T})$ is the number of days with dust storms out of the total number of sampling days/month.

${ }^{b} \%$ is the percentage days with dust storms as related to the total sampling days/month.

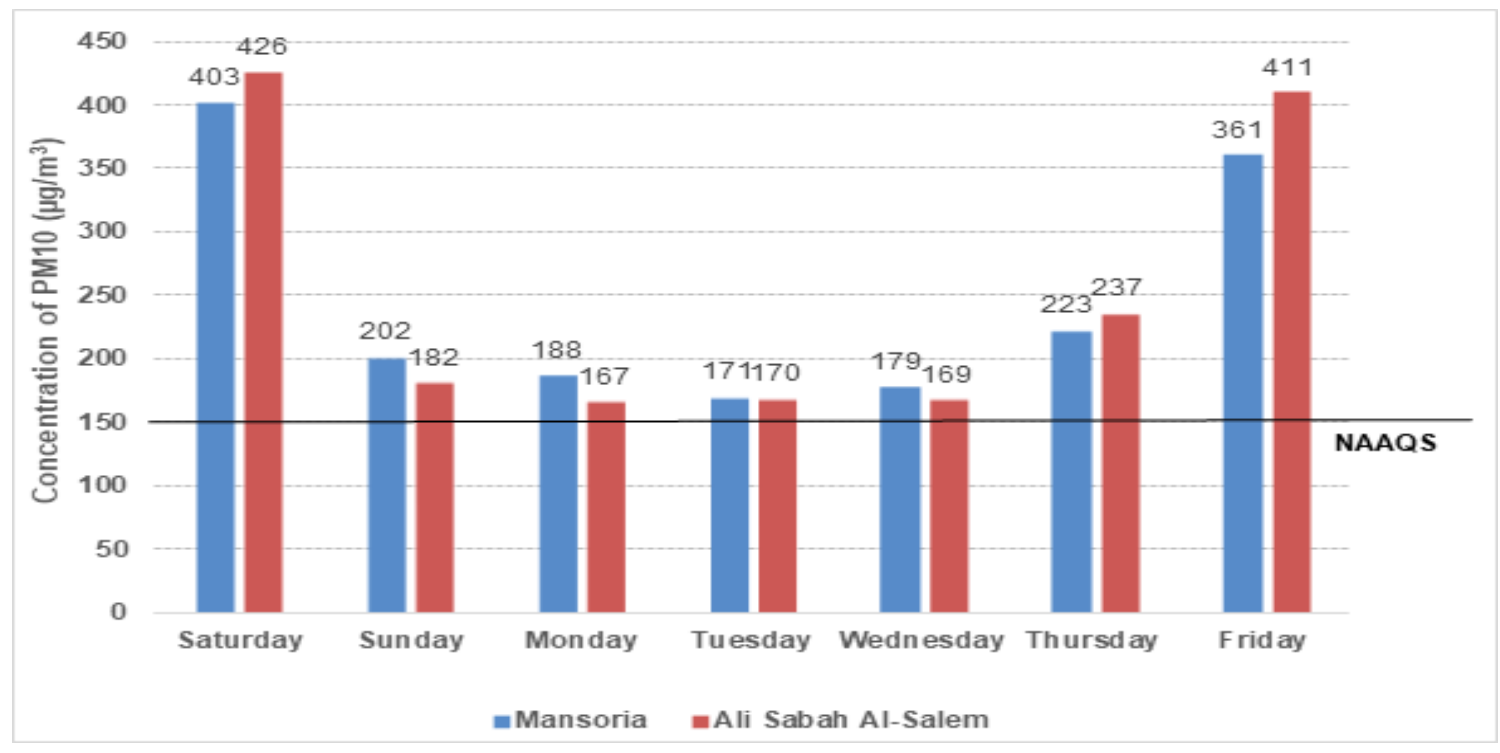

Fig. 3: Daily medians of respirable particulates (PM10) in Mansoria and Ali Sabah El-Salem Monitoring Stations, Kuwait, 2013. 
In both Mansoria and Ali Sabah Al-Salem, during all months, the concentrations of PM10 during days with dust storms were significantly higher than that during days without dust storms $(P<0.05,95 \% \mathrm{CI})$, except in the second station during November (Table 2). The annual
PM10 concentration of Ali Sabah Al-Salem [192.5 (264.5)] was nonsignificantly higher than that of Mansoria [191.2 (182.7)]. During most of the year, the concentrations of PM10 during days with dust storms were higher in Ali Sabah Al-Salem than in Mansoria.

Table 2: Monthly medians of PM10 concentrations in days without and with dust storms in Mansoria and Ali Sabah Al-Salem monitoring station, Kuwait, 2013

\begin{tabular}{|c|c|c|c|c|c|c|c|c|c|c|c|c|c|}
\hline \multirow[t]{2}{*}{ Months } & \multirow[t]{2}{*}{ Case } & \multicolumn{6}{|c|}{ Mansoria } & \multicolumn{6}{|c|}{ Ali Sabah Al-Salem } \\
\hline & & $\mathrm{No}^{1}$ & Median $^{2}$ & $\mathrm{Q} 1^{3}$ & $\mathrm{Q}^{4}$ & $\mathrm{IQR}^{5}$ & P-value ${ }^{6}$ & No & Median & Q1 & Q3 & IQR & P-value \\
\hline January & $\begin{array}{l}\text { Without } \\
\text { With }\end{array}$ & $\begin{array}{c}16 \\
7\end{array}$ & $\begin{array}{l}127.2 \\
548.4\end{array}$ & $\begin{array}{l}104.4 \\
258.0\end{array}$ & $\begin{array}{c}158.6 \\
1860.1\end{array}$ & $\begin{array}{c}54.2 \\
1602.1\end{array}$ & $<0.05$ & $\begin{array}{c}15 \\
9\end{array}$ & $\begin{array}{l}143.1 \\
827.2\end{array}$ & $\begin{array}{l}122.8 \\
270.2\end{array}$ & $\begin{array}{c}155.2 \\
1896.8\end{array}$ & $\begin{array}{c}32.4 \\
1626.6\end{array}$ & $<0.05$ \\
\hline February & $\begin{array}{c}\text { Without } \\
\text { With }\end{array}$ & $\begin{array}{c}14 \\
6\end{array}$ & $\begin{array}{l}130.9 \\
246.0\end{array}$ & $\begin{array}{l}118.1 \\
216.4\end{array}$ & $\begin{array}{l}169.9 \\
600.8\end{array}$ & $\begin{array}{c}51.8 \\
384.4\end{array}$ & $<0.05$ & $\begin{array}{c}17 \\
4\end{array}$ & $\begin{array}{l}140.8 \\
438.7\end{array}$ & $\begin{array}{l}102.7 \\
280.0\end{array}$ & $\begin{array}{l}167.5 \\
843.5\end{array}$ & $\begin{array}{c}64.8 \\
563.5\end{array}$ & $<0.05$ \\
\hline March & $\begin{array}{c}\text { Without } \\
\text { With }\end{array}$ & $\begin{array}{c}12 \\
8\end{array}$ & $\begin{array}{l}126.5 \\
300.2\end{array}$ & $\begin{array}{l}102.2 \\
248.3\end{array}$ & $\begin{array}{l}177.8 \\
364.9\end{array}$ & $\begin{array}{c}75.6 \\
116.6\end{array}$ & $<0.05$ & $\begin{array}{c}7 \\
15\end{array}$ & $\begin{array}{l}133.7 \\
433.5\end{array}$ & $\begin{array}{l}106.1 \\
320.1\end{array}$ & $\begin{array}{l}169.6 \\
677.2\end{array}$ & $\begin{array}{c}63.5 \\
357.0\end{array}$ & $<0.05$ \\
\hline April & $\begin{array}{l}\text { Without } \\
\text { With }\end{array}$ & $\begin{array}{l}11 \\
10\end{array}$ & $\begin{array}{l}124.4 \\
338.2\end{array}$ & $\begin{array}{l}106.3 \\
260.7\end{array}$ & $\begin{array}{l}183.3 \\
446.6\end{array}$ & $\begin{array}{c}77.0 \\
185.9\end{array}$ & $<0.05$ & $\begin{array}{l}11 \\
11\end{array}$ & $\begin{array}{l}142.2 \\
451.2\end{array}$ & $\begin{array}{l}102.5 \\
297.4\end{array}$ & $\begin{array}{l}168.6 \\
857.5\end{array}$ & $\begin{array}{c}66.1 \\
560.1\end{array}$ & $<0.05$ \\
\hline May & $\begin{array}{l}\text { Without } \\
\text { With }\end{array}$ & $\begin{array}{l}9 \\
9\end{array}$ & $\begin{array}{c}122.6 \\
332.3\end{array}$ & $\begin{array}{l}103.1 \\
268.6\end{array}$ & $\begin{array}{l}132.1 \\
525.7\end{array}$ & $\begin{array}{c}29.0 \\
257.1\end{array}$ & $<0.05$ & $\begin{array}{l}8 \\
14\end{array}$ & $\begin{array}{l}159.7 \\
526.9\end{array}$ & $\begin{array}{r}97.5 \\
249.7\end{array}$ & $\begin{array}{l}172.7 \\
875.4\end{array}$ & $\begin{array}{c}75.2 \\
625.7\end{array}$ & $<0.05$ \\
\hline June & $\begin{array}{l}\text { Without } \\
\text { With }\end{array}$ & $\begin{array}{c}5 \\
21\end{array}$ & $\begin{array}{l}137.4 \\
540.9\end{array}$ & $\begin{array}{l}118.2 \\
297.2\end{array}$ & $\begin{array}{l}158.2 \\
874.7\end{array}$ & $\begin{array}{c}40.0 \\
577.5\end{array}$ & $<0.05$ & $\begin{array}{c}4 \\
25\end{array}$ & $\begin{array}{l}165.3 \\
586.0\end{array}$ & $\begin{array}{l}150.8 \\
369.1\end{array}$ & $\begin{array}{c}186.9 \\
1344.3\end{array}$ & $\begin{array}{c}36.1 \\
975.2\end{array}$ & $<0.05$ \\
\hline July & $\begin{array}{l}\text { Without } \\
\text { With }\end{array}$ & $\begin{array}{c}5 \\
20\end{array}$ & $\begin{array}{l}159.7 \\
323.0\end{array}$ & $\begin{array}{l}122.1 \\
248.1\end{array}$ & $\begin{array}{l}186.6 \\
424.3\end{array}$ & $\begin{array}{c}64.5 \\
176.1\end{array}$ & $<0.05$ & $\begin{array}{c}4 \\
22\end{array}$ & $\begin{array}{l}156.7 \\
394.5\end{array}$ & $\begin{array}{l}144.9 \\
292.1\end{array}$ & $\begin{array}{l}176.6 \\
602.0\end{array}$ & $\begin{array}{c}31.7 \\
309.9\end{array}$ & $<0.05$ \\
\hline August & $\begin{array}{l}\text { Without } \\
\text { With }\end{array}$ & $\begin{array}{c}14 \\
7\end{array}$ & $\begin{array}{l}180.1 \\
277.2\end{array}$ & $\begin{array}{l}165.8 \\
229.0\end{array}$ & $\begin{array}{l}189.0 \\
626.1\end{array}$ & $\begin{array}{c}23.3 \\
397.1\end{array}$ & $<0.05$ & $\begin{array}{c}8 \\
14\end{array}$ & $\begin{array}{l}164.1 \\
235.9\end{array}$ & $\begin{array}{l}142.6 \\
217.0\end{array}$ & $\begin{array}{l}172.7 \\
415.8\end{array}$ & $\begin{array}{c}30.1 \\
198.8\end{array}$ & $<0.05$ \\
\hline September & $\begin{array}{l}\text { Without } \\
\text { With }\end{array}$ & $\begin{array}{c}8 \\
12\end{array}$ & $\begin{array}{l}157.3 \\
338.5\end{array}$ & $\begin{array}{l}131.6 \\
226.0\end{array}$ & $\begin{array}{l}173.5 \\
447.1\end{array}$ & $\begin{array}{c}41.9 \\
221.1\end{array}$ & $<0.05$ & $\begin{array}{l}11 \\
11\end{array}$ & $\begin{array}{l}144.4 \\
269.7\end{array}$ & $\begin{array}{l}135.8 \\
241.3\end{array}$ & $\begin{array}{l}174.6 \\
360.3\end{array}$ & $\begin{array}{c}38.8 \\
119.0\end{array}$ & $<0.05$ \\
\hline October & $\begin{array}{l}\text { Without } \\
\text { With }\end{array}$ & $\begin{array}{c}10 \\
9\end{array}$ & $\begin{array}{l}132.0 \\
303.9\end{array}$ & $\begin{array}{l}101.8 \\
245.8\end{array}$ & $\begin{array}{l}158.7 \\
383.7\end{array}$ & $\begin{array}{c}56.9 \\
137.9\end{array}$ & $<0.05$ & $\begin{array}{c}16 \\
3\end{array}$ & $\begin{array}{l}127.9 \\
416.3\end{array}$ & $\begin{array}{l}115.7 \\
264.9\end{array}$ & $\begin{array}{c}156.5 \\
-\end{array}$ & $\begin{array}{c}40.8 \\
-\end{array}$ & $<0.05$ \\
\hline November & $\begin{array}{l}\text { Without } \\
\text { With }\end{array}$ & $\begin{array}{c}14 \\
4\end{array}$ & $\begin{array}{l}105.5 \\
245.0\end{array}$ & $\begin{array}{c}78.9 \\
217.2\end{array}$ & $\begin{array}{l}141.9 \\
291.2\end{array}$ & $\begin{array}{l}63.0 \\
74.0\end{array}$ & $<0.05$ & $\begin{array}{c}18 \\
1\end{array}$ & $\begin{array}{c}87.4 \\
272.1\end{array}$ & $\begin{array}{c}66.3 \\
-\end{array}$ & $\begin{array}{c}109.6 \\
-\end{array}$ & $\begin{array}{c}43.2 \\
-\end{array}$ & $>0.05$ \\
\hline December & $\begin{array}{c}\text { Without } \\
\text { With }\end{array}$ & $\begin{array}{c}19 \\
6\end{array}$ & $\begin{array}{c}96.6 \\
291.6\end{array}$ & $\begin{array}{c}73.4 \\
245.3\end{array}$ & $\begin{array}{l}123.8 \\
595.2\end{array}$ & $\begin{array}{c}50.4 \\
349.9\end{array}$ & $<0.05$ & $\begin{array}{c}20 \\
5\end{array}$ & $\begin{array}{l}105.0 \\
360.5\end{array}$ & $\begin{array}{c}93.5 \\
217.9\end{array}$ & $\begin{array}{l}127.0 \\
872.5\end{array}$ & $\begin{array}{c}33.5 \\
654.6\end{array}$ & $<0.05$ \\
\hline
\end{tabular}

1: Number of measurement days.

2 :The middle value of the ranked ordered data set.

3: The middle value of the first half of the ranked ordered data set.

4: The middle value of the second half of the ranked ordered data set.

5: The difference between Q3 and Q1.

6: $P$-value using Mann-Whitney test.

7: Without dust storms.

8: With dust storms. 
In Mansoria, the prevailing wind directions all over the years were the north-west and west-north west. However, in Ali Sabah Al-Salem, the most common prevailing wind directions are the north-west and west-north west, in addition to west, south-south east, east, east-north east, and south. During June and July, the prevailing wind directions in both Mansoria and Ali Sabah Al-Salem were north-west (Table 3).

Table 3: Monthly prevailing wind directions in Mansoria and Ali Sabah Al-Salem areas, Kuwait, 2013

\begin{tabular}{|c|c|c|}
\hline \multirow[t]{2}{*}{ Month } & \multicolumn{2}{|c|}{ Prevailing wind direction (deg.) } \\
\hline & Mansoria & Ali Sabah Al-Salem \\
\hline January & NW & $\mathrm{W}$ and $\mathrm{WNW}$ \\
\hline February & NW & WNW \\
\hline March & NW & WNW, SSE, E \\
\hline April & WNW and NW & $\mathrm{E}, \mathrm{ENE}$ \\
\hline May & NW and WNW & E, WNW, ENE \\
\hline June & NW & NW \\
\hline July & NW and WNW & NW \\
\hline August & WNW and NW & WNW, ENE \\
\hline September & WNW and NW & WNW \\
\hline October & NW and WNW & WNW, ENE, and W \\
\hline November & WNW and NW & ENE, WNW \\
\hline December & NW and WNW & SSE, WNW, S \\
\hline
\end{tabular}

E, east; N, north; S, south; W, west.

In both Mansoria and Ali Sabah Al-Salem, June and July were of the highest wind speed. However, June, July, August, and September were of the highest air temperatures in the two residential areas (Fig. 4). In the two monitoring stations, June, July, and August had the lowest relative humidity, and atmospheric pressures (Fig. 5).

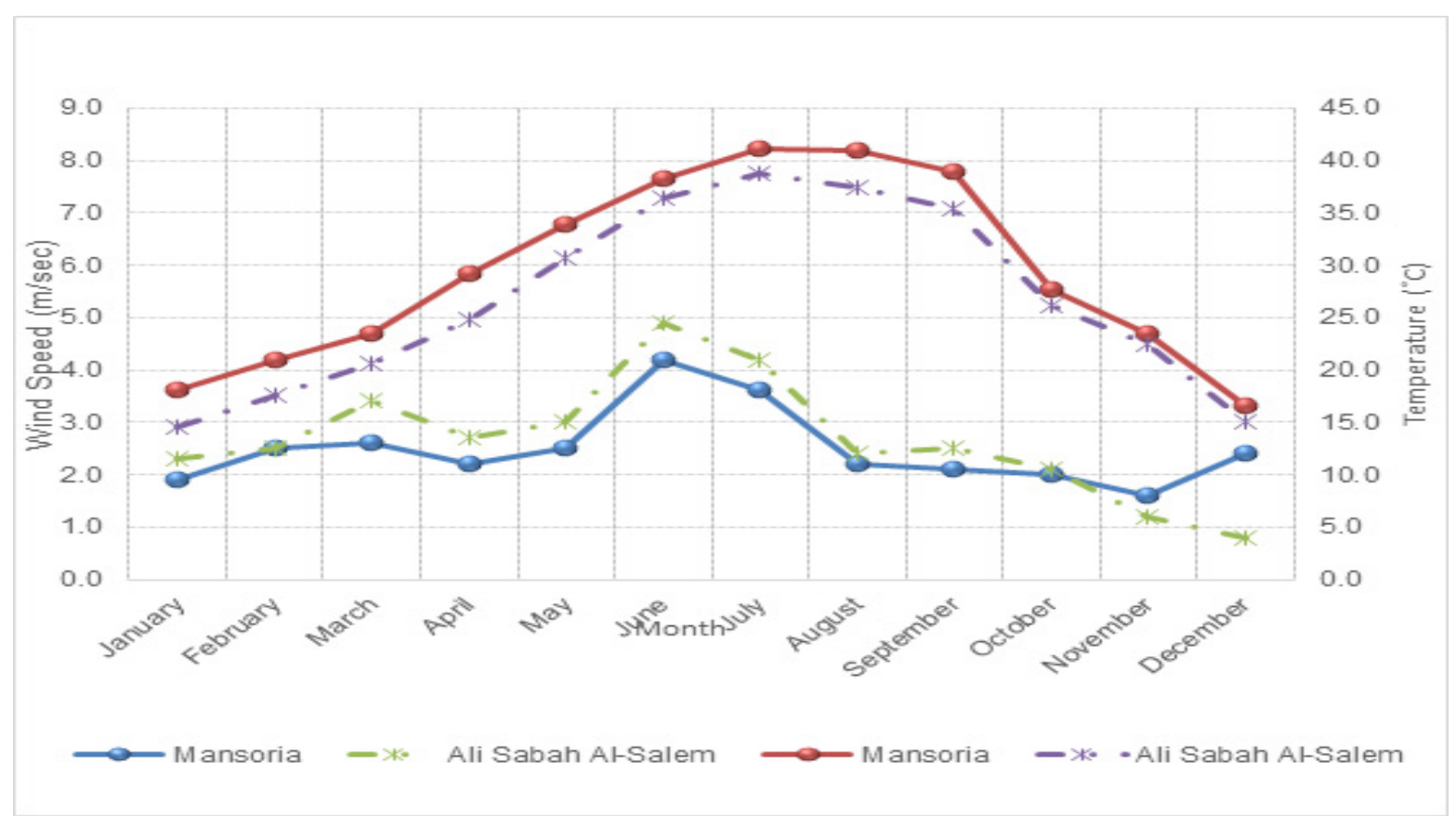

Fig. 4: Monthly wind speed and air temperature in Mansoria and Ali Sabah Al-Salem, Kuwait, 2013. 


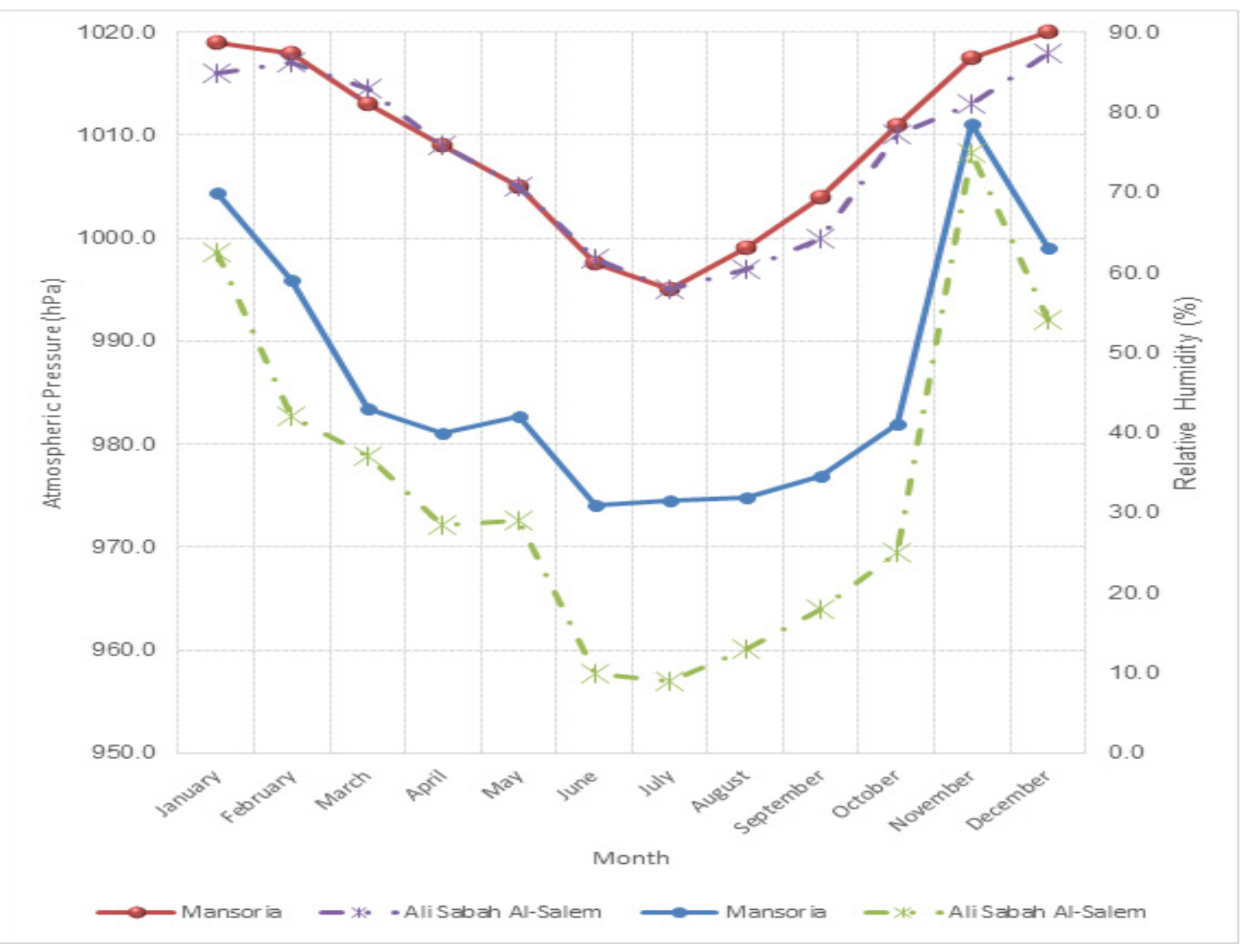

Fig. 5: Monthly atmospheric pressure and relative humidity in Mansoria and Ali Sabah Al-Salem, Kuwait, 2013.

\section{DISCUSSION}

Unlike most of the researches, the concentrations of PM10 in this study during weekends were significantly greater than that during weekdays in both Mansoria and Ali Sabah Al-Salem. A Southern California $(2004)^{[24]}$, a Brazilian study $(2013)^{[25]}$, and a Korean one $(2017)^{[26]}$ concluded higher weekdays than weekends' concentrations. They explained this finding based on the high-traffic activities during weekdays that increase exhaust emissions, corrosion of tires, brakes, and roads that enhance PM10 excitation. In Mansoria and Ali Sabah AlSalem, 100 and $87.7 \%$ of the weekends, respectively, were affected by dust storms' events; and this may be the main cause of the observed contradiction with the other studies.

In both Mansoria and Ali Sabah Al-Salem, during all months, the concentrations of PM10 during days with dust storms were significantly higher than that during days without dust storms. An Arabian Peninsula study $(2018)^{[27]}$ and an Indian study (2017) ${ }^{[28]}$ reported high PM10 concentrations during dust storms' episodes owing to large distance travels of particulate matters.
In most months, the PM10 levels during days with dust storms were higher in Ali Sabah Al-Salem than Mansoria. This may be attributed to human activities and meteorological parameters. Regarding human activities, the two areas have similar commercial, and traffic activities, but the Ali Sabah Al-Salem is downwind the industrial activities at the west, north west, and north, which were the prevailing wind directions all over the year ${ }^{[15,16]}$. Regarding meteorological parameters, the air temperature and relative humidity in Mansoria were higher than that in Ali Sabah Al-Salem. The wind speed in Mansoria was lower than that in Ali Sabah Al-Salem. This reduced the PM10 levels in Mansoria $^{[29]}$

During November, in Ali Sabah Al-Salem, the concentrations of PM10 during days without dust storms were nonsignificantly lower than those with. This nonsignificance was owing to the presence of only 1 day with dust storm during this month. So the significance of variation could not be estimated.

June and July were the months of the highest PM10 concentrations in both Mansoria and Ali Sabah Al-Salem. This can be explained based on meteorological factors, 
where these 2 months were of the highest wind speed and the lowest relative humidity in the two residential sites. A study conducted in Kathmandu Valley in 2008 ${ }^{[30]}$, and another one in Korea in $2006^{[31]}$ established a direct relation of PM10 concentrations and wind speed and an inverse relation with relative humidity.

\section{LIMITATIONS OF STUDY}

The lack of hospital admission, morbidity, and mortality data to be correlated with dust storms events represents a limitation of this study. Based on our limited knowledge, no major changes were conducted in the two residential areas after the study. In addition, we do not have any concentration data after the study.

\section{CONCLUSION}

The daily respirable particulates' concentrations in the two residential areas in Kuwait State are very high as compared with the ambient air quality standards. This situation may cause poor ambient air quality and deterioration of public health. The annual levels of PM10 is slightly higher in Ali Sabah Al-Salem than in Mansoria. Days with dust storms have greater PM10 levels than those without.

The results of the present study motivate most countries to use the basis of land-use planning in designing new residential areas (residential areas must be upwind the industrial ones). It also urges the governments and media to enhance public to stop all outdoor activities during dust storms. In addition, establishing windbreaks around the residential areas, and combating desertification in Kuwait may mitigate the effects of dust storms. Further research dealing with the chemical composition of PM10 and its correlation with hospital admission, morbidity, and mortality data is recommended. Moreover, additional study interested in risk assessment of dust storms in Kuwait is also advised.

\section{REFERENCES}

1. Al-TaiarA, Thalib L. Short-term effect of dust storms on the risk of mortality due to respiratory, cardiovascular and all-causes in Kuwait. Int $\mathrm{J}$ Biometeorol 2014; 58: 69-77.

2. Islam M, Almazroui M. Direct effects and feedback of desert dust on the climate of the Arabian Peninsula during the wet season: a regional climate model study. Clim Dyn 2012; 39: 2239-2250.

3. Pannullo F, Lee D, Neal L, Dalvi M, Agnew P, O'Connor FM, et al. Quantifying the impact of current and future concentrations of air pollutants on respiratory disease risk in England. Environ Health 2017; 16: 29.
4. Teng JCY, Chan YS, Peng YI, Liu TC. Influence of Asian dust storms on daily acute myocardial infarction hospital admissions. Public Health Nurs 2016; 33: 118-128.

5. Muller CO, Yu H, Zhu B. Ambient Air Quality in China: the impact of particulate and gaseous pollutants on IAQ. Procedia Eng 2015; 121: 582-589.

6. Fortelli A, Scafetta N, Mazzarella A. Influence of synoptic and local atmospheric patterns on PM10 air pollution levels: a model application to Naples (Italy). Atmos Environ 2016; 143: 218-228.

7. Maleki H, Sorooshian A, Goudarzi G, Nikfal A, Baneshi MM. Temporal profile of PM10 and associated health effects in one of the most polluted cities of the world (Ahvaz, Iran) between 2009 and 2014. Aeolian Res 2016; 22: 135-140.

8. Goudie AS, Middleton NJ. The changing frequency of dust storms through time. Clim Change 1992; 20:197-225.

9. Hamza W, Enan MR, Al-Hassini H, Stuut JB, deBeer D. Dust storms over the Arabian Gulf: a possible indicator of climate changes consequences. Aquat Ecosyst Health Manag 2011; 14:260-268.

10. Gupta M, Mohan M. Assessment of contribution to PM10 concentrations from long range transport of pollutants using WRF/Chem over a subtropical urban airshed. Atmos Pollut Res 2013; 4:405-410.

11. Luong LMT, Phung D, Sly PD, Morawska L, Thai PK. The association between particulate air pollution and respiratory admissions among young children in Hanoi, Vietnam. Sci Total Environ 2017; 578: 249-255.

12. Emmanouil C, Drositi E, Vasilatou V, Diapouli E, Krikonis K, Eleftheriadis K, et al. Study on particulate matter air pollution, source origin, and human health risk based of PM10 metal content in Volos City, Greece. Toxicol Environ Chem 2017; 99:691-709.

13. Sprigg WA, Nickovic S, Galgiani JN, Pejanovic G, Petkovic S, Vujadinovic M, et al. Regional dust storm modeling for health services: the case of valley fever. Aeolian Res 2014; 14: 53-73.

14. Miri A, Ahmadi H, Panjehkeh N, Ghanbari A, Moghaddamnia A, Galavi M. Dust storms impact on air pollution and public health: a case study in Iran. In: Perlovsky L, Sandberg IW, Halkias D, editors. Proceedings of the 2nd WSEAS International 
Conference on Management, Marketing and Finances: Recent Advances on Development and Financial Engineering. Mathematics and Computers in Science and Engineering. Athens: World Scientific and Engineering Acad and Soc; 2008. pp. 134-213.

15. Al-Salem S, Al-Fadhlee A, Khan A. Ambient air quality assessment of Al-Mansoriah residential area in the state of Kuwait. J Engin Res 2009; 6:52-63.

16. Al-Awadi LT, Popov V, Khan A. Seasonal effects of major primary pollutants in Ali Sabah Al-Salem residential area in Kuwait. Int J Environ Technol Manag 2015; 18:54-82.

17. Aili A, Kim Oanh NT. Effects of dust storm on public health in desert fringe area: case study of northeast edge of Taklimakan Desert, China. Atmos Pollut Res 2015 ; 6:805-814.

18. Sabbah I. Impact of aerosol on air temperature in Kuwait. Atmos Res 2010; 97:303-314.

19. Al-Rashidi M, Nassehi V, Wakeman R. Investigation of the efficiency of existing air pollution monitoring sites in the state of Kuwait. Environ Pollut 2005; 138:219-229.

20. Khordagui HK, Al-Ajmi DN. Application of indices for air quality management in Kuwait. Environ Manage 1996; 20:151-158.

21. Daniel B, Nathan T. Ecotech 3000High Volume PM10 Sampler. In: Department SaI, editor. 1st edition California; 2015, p. 1-27

22. Rosner B. Fundamentals of biostatistics: Nelson Education Cengage Learning, Inc; Boston, USA; 2010; p. 327-344.

23. Ott RL, Longnecker MT. An introduction to statistical methods and data analysis: Nelson Education 6th edition, Cengage Learning, Inc; Boston,
USA; 2010; p. 478-482.

24. Qin Y, Tonnesen GS, Wang Z. Weekend/weekday differences of ozone, NOx, CO, VOCs, PM10 and the light scatter during ozone season in southern California. J Atmos Environ 2004; 38:3069-3087.

25. Agudelo-Castaneda DM, Teixeira EC, Schneider IL, Pereira FN, Oliveira MLS, Taffarel SR, et al. Potential utilization for the evaluation of particulate and gaseous pollutants at an urban site near a major highway. Sci Total Environ 2016; 543:161-170.

26. Jang E, Do W, Park G, Kim M, Yoo E. Spatial and temporal variation of urban air pollutants and their concentrations in relation to meteorological conditions at four sites in Busan, South Korea. Atmos Pollut Res 2017; 8:89-100.

27. Beegum SN, Gherboudj I, Chaouch N, Temimi M, Ghedira H. Simulation and analysis of synoptic scale dust storms over the Arabian Peninsula. Atmos Res 2018; 199:62-81.

28. Yadav R, Sahu LK, Beig G, Tripathi N, Jaaffrey SNA Ambient particulate matter and carbon monoxide at an urban site of India: influence of anthropogenic emissions and dust storms. Environ Pollut 2017; 225:291-303.

29. Toro AR, Morales SRGE, Canales M, Gonzalez-Rojas C, Leiva GMA. Inhaled and inspired particulates in Metropolitan Santiago Chile exceed air quality standards. Build Environ 2014; 79:115-123.

30. Giri D, Murthy VK, Adhikary P. The influence of meteorological conditions on PM10 concentrations in Kathmandu valley. Int J Environ Res 2008; 2:49-60.

31. Jo WK, Lee JY. Indoor and outdoor levels of respirable particulates (PM10) and carbon monoxide (CO) in high-rise apartment buildings. Atmos Environ 2006; 40:6067-6076. 